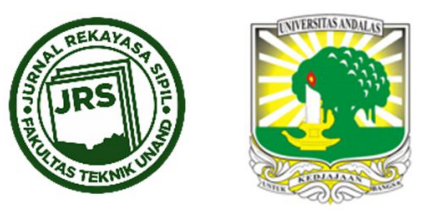

\title{
PENENTUAN TINGKAT AKURASI BEBERAPA METODE PREDIKSI EFISIENSI TANGKAPAN (TRAP EFFICIENCY) SEDIMEN DI WADUK MRICA
}

\author{
PUJI UTOMO ${ }^{*}$, PRISCA FEBRIANI ${ }^{1}$ \\ ${ }^{1}$ Program Studi Teknik Sipil, Universitas Teknologi Yogyakarta, Yogyakarta, Indonesia \\ *Corresponding author: $₫$ puji.utomo@staff.uty.ac.id
}

Naskah diterima : 12 Mei 2021. Disetujui: 08 Agustus 2021

\begin{abstract}
ABSTRAK
Sedimentasi waduk merupakan permasalahan global yang sangat penting dalam perencanaan waduk karena menyebabkan penurunan kapasitas tampungan waduk. Dalam menghitung sedimentasi waduk, biasanya meliputi sedimen yang masuk, sedimen yang keluar, dan endapan sedimen di dalam waduk, sehingga didapatkan imbangan sedimen yang terjadi. Namun dalam praktik di lapangan, tidak semua melakukan ketiga perhitungan tersebut, karena pertimbangan biaya pelaksanaan yang cukup mahal. Untuk mengatasi hal tersebut, perhitungan sedimentasi dilakukan dengan pendekatan konsep efisiensi tangkapan (trap efficiency) sedimen. Selama ini pendekatan konsep ini didasarkan pada hasil penelitian di luar negeri dan tingkat akurasi masih belum optimal. Tujuan penelitian ini untuk mengetahui tingkat akurasi dari beberapa metode prediksi efisiensi tangkapan sedimen. Penelitian ini dilakukan di Waduk Mrica, Kabupaten Banjarnegara. Data-data yang diperlukan berupa data sekunder, seperti: data debit inflow, data rating curve debit sedimen, data pengukuran echosounding, data analisa butiran sedimen dasar waduk, dan data teknis waduk. Tahapan yang dilakukan dalam penelitian ini, diantaranya: menghitung sedimen yang masuk, sedimen yang mengendap, efisiensi tangkapan, dan mendapatkan tingkat akurasi dari beberapa metode yang ditinjau. Kriteria statistik dari metode terpilih harus memiliki nilai korelasi $>0,6$ dan error $<20 \%$. Imbangan sedimen di Waduk Mrica menunjukkan bahwa laju sedimen yang masuk sebesar 6,001 juta $\mathrm{m}^{3} /$ tahun. Sedimen rerata yang mengendap sebesar 3,850 juta $\mathrm{m}^{3} /$ tahun, sehingga sedimen yang dikeluarkan rerata sebesar 2,151 juta $\mathrm{m}^{3}$ /tahun. Tingkat akurasi dari metode prediksi efisiensi tangkapan bervariasi dari sedang sampai kuat. Metode prediksi efisiensi tangkapan sedimen Brune, Harbor dkk, dan Jotihiprakash dan Garg dianggap paling representatif untuk digunakan pada Waduk Mrica.
\end{abstract}

Kata kunci : Imbangan Sedimen, Trap Efficiency, Sedimentasi Waduk, Tingkat Akurasi, Waduk Mrica

\section{PENDAHULUAN}

Sedimentasi waduk merupakan permasalahan global yang sangat penting dalam perencanaan waduk karena menentukan keberlanjutan fungsi waduk. Sedimentasi merupakan hasil akumulasi material sedimen yang tererosi di lahan DAS sampai ke waduk 
dan mengalami pengendapan atau sedimentasi, baik pengendapan permanen maupun sementara. Sedimentasi waduk yang tidak terkendali akan sangat mempengaruhi unjuk kerja waduk, karena menyebabkan usia layanan waduk tidak sesuai dengan umur perencanaan. Banyak waduk di Pulau Jawa sendiri yang mengalami degradasi volume tampungan air akibat dari sedimen yang berasal dari erosi lahan, salah satunya Waduk Mrica. Menurut Utomo (2017) laju erosi lahan rerata tahunan di DAS Waduk Mrica mencapai 5,477 juta $\mathrm{m}^{3} /$ tahun.

Hasil penelitian Febriani dan Utomo (2018) di Waduk Mrica sedimen yang masuk sebesar 6,543 juta $\mathrm{m}^{3} /$ tahun dan volume sedimen yang mengendap sebesar $3,955 \mathrm{~m}^{3} /$ tahun. Widarto (2017) menyatakan proses sedimentasi yang masuk ke Waduk Mrica rata-rata 4,2 juta $\mathrm{m}^{3}$ /tahun dengan timbunan sedimen $106,3 \mathrm{~m}^{3}$ atau $71 \%$ dari kapasitas tampungan mati. Drajati dan Utomo (2018) sedimen yang masuk sebesar 5,869 juta $\mathrm{m}^{3} /$ tahun, laju sedimentasi sebesar 4,097 juta $\mathrm{m}^{3} /$ tahun, sehingga sedimen yang dikeluarkan sebesar 1,772 juta $\mathrm{m}^{3}$ /tahun. Hasil studi Perum Jasa Tirta I (2015) umur layanan Waduk Mrica diprediksikan akan berakhir pada tahun 2022 jika tanpa ada pengelolaan sedimentasi.

Dalam perhitungan sedimentasi, biasanya meliputi debit sedimen masuk (sediment inflow), debit sedimen keluar (sediment outflow) dan endapan sedimen di dalam waduk (sediment deposited). Selanjutnya dapat ditentukan imbangan sedimen (sediment balance), yaitu masukan dan keluaran sedimen di waduk pada periode tertentu. Namun dalam praktik di lapangan, tidak semua pengelola waduk melakukan ketiga analisis tersebut dalam satu periode tertentu, karena pertimbangan biaya pelaksanaan yang cukup mahal. Untuk mengatasi hal tersebut, analisis sedimentasi di waduk dapat dilakukan dengan pendekatan efisiensi tangkapan (trap efficiency) sedimen dari suatu waduk.

Efisiensi tangkapan (trap efficiency) sedimen sebuah waduk didefinisikan sebagai persentase dari total sedimen yang mengendap di dalam waduk terhadap sedimen yang masuk ke waduk. Selama ini pendekatan konsep ini didasarkan pada hasil penelitian di luar negeri, seperti Brown (1944), Churchill (1948), Brune (1953), Dendy (1974), Gill (1979), Heinmann (1981), Harbor et al (1997), Siyam (2000), Verstraeten dan Poesen (2000), dan Jothiprakash dan Garg (2008). Di Indonesia, sepengetahuan penulis hanya penelitian Susilo (2001) yang mengkaji tingkat akurasi dan melakukan modifikasi terhadap metode prediksi Brown (1944), Churchill (1947), Brune (1953) dengan menggunakan data dari 13 waduk yang ada di Pulau Jawa. Dari semua metode prediksi efisiensi tangkapan sedimen waduk yang dianalisis oleh Susilo (2001), metode Brune yang telah dimodifikasi adalah metode terbaik. Oleh karena itu, masih dimungkinkan untuk melakukan penelitian untuk melihat tingkat akurasi dari beberapa metode efisiensi tangkapan sedimen. Diharapkan dengan penelitian ini, dapat digunakan sebagai acuan oleh pihak pengelola waduk dalam pengambilan kebijakan dan strategi pengelolaan sedimentasi di waduk.

\section{METODE PENELITIAN}

Waduk Mrica dibangun pada tahun 1983 dan mulai beroperasi pada tahun 1988. Lokasi keberadaan Waduk Mrica ditunjukkan pada Gambar 1. Secara geografis, terletak pada posisi $7^{\circ}$ LS dan $110^{\circ}$ BT. Secara administratif, Waduk Mrica terletak di Kecamatan Bawang, Kabupaten Banjarnegara, Jawa Tengah. Waduk Mrica merupakan waduk buatan yang dibangun dengan membendung sungai Serayu pada DAS Serayu Bogowonto. Daerah tangkapan air Waduk Mrica luasnya mencapai $957 \mathrm{~km}^{2}$ dan kapasitas tampungan sebesar 193,5 juta $\mathrm{m}^{3}$. 


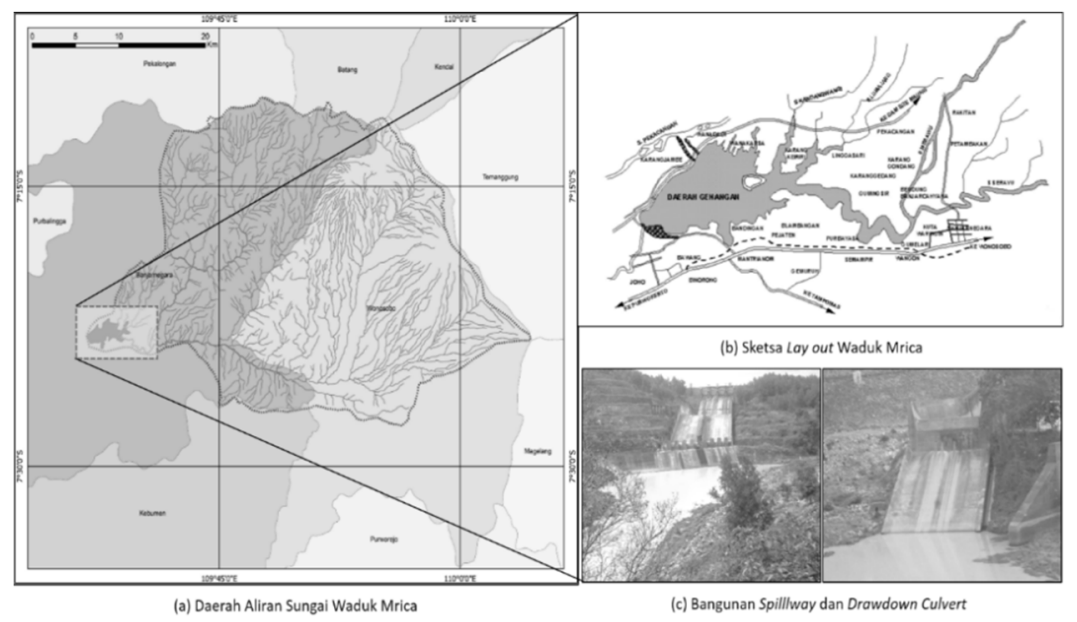

Gambar 1. Lokasi Waduk Mrica (Utomo, 2018)

Data-data yang diperlukan dalam penelitian ini adalah data sekunder yang diperoleh dari berbagai instansi, seperti : Data debit inflow tahun 2001 - 2015, data rating curve debit sedimen, data pengukuran echosounding tahun 2001 - 2015, data analisa butiran sedimen dasar waduk, data teknis waduk, dan data dokumen/laporan pendukung terkait studi terdahulu di Waduk Mrica. Setelah meninjau ulang penelitian terdahulu dan pengumpulan data, maka selanjutnya dilakukan pengolahan data. Tahapan analisis data yang dilakukan dalam penelitian ini adalah sebagai berikut:

\section{Menghitung volume sedimen yang masuk}

Besaran volume sedimen yang masuk per tahun merupakan total dari volume sedimen melayang (suspended load) dan sedimen muatan dasar (bed load). Besaran debit sedimen melayang (suspended load) didapatkan dari hasil rating curve debit sedimen. Besaran debit sedimen muatan dasar (bed load) melalui pendekatan rumus empirik dari Meyer-PetterMuller (1948). Hasil rating curve debit sedimen di tiga sungai utama dari PT. Indonesia Power adalah sebagai berikut:

$$
\begin{array}{ll}
\text { Sungai Serayu } & : Q_{\mathrm{S}}=0,756 \times \mathrm{Q}_{\mathrm{w}}{ }^{2,084} \\
\text { Sungai Merawu } & : \mathrm{Q}_{\mathrm{S}}=26,525 \times \mathrm{Q}_{\mathrm{w}}{ }^{1,745} \\
\text { Sungai Lumajang } & : \mathrm{Q}_{\mathrm{S}}=11,7372 \times \mathrm{Q}_{\mathrm{w}}{ }^{2,8864}
\end{array}
$$

dimana, $Q_{\mathrm{s}}$ adalah angkutan sedimen sungai $(\mathrm{kg} / \mathrm{s})$ dan $\mathrm{Q}_{\mathrm{W}}$ adalah debit sungai $\left(\mathrm{m}^{3} / \mathrm{s}\right)$

Perhitungan sedimen dasar (bed load) dihitung melalui pendekatan rumus empirik dari Meyer-Petter-Muller (1948), sebagaimana disajikan sebagai berikut:

$$
Q_{b}^{\frac{2}{3}}=\left(\frac{\gamma_{w}\left(\frac{K_{s}}{K_{r}}\right)^{\frac{3}{2}} R S-0,047\left(\gamma_{s}-\gamma_{w}\right) d}{0,25\left(\frac{\gamma_{w}}{g}\right)^{\frac{1}{3}}}\right) \div \frac{1}{\left(\gamma_{s}-\gamma_{w}\right)}\left(\frac{1}{1-e}\right) L
$$

dimana $Q_{b}$ adalah debit sedimen dasar $\left(\mathrm{m}^{3} / \mathrm{s}\right), \Upsilon_{\mathrm{w}}$ adalah berat jenis air $\left(\right.$ ton $\left./ \mathrm{m}^{3}\right), \Upsilon_{\mathrm{s}}$ adalah berat jenis sedimen (ton $/ \mathrm{m}^{3}$ ), $\mathrm{R}$ adalah jari-jari hidraulik $(\mathrm{m}), \mathrm{S}$ adalah kemiringan dasar 
sungai, d adalah diameter media $\mathrm{d}_{50}-\mathrm{d}_{60}(\mathrm{~m})$, g adalah percepatan gravitasi $\mathrm{m} / \mathrm{s}^{2}$, e adalah angka pori, $\mathrm{Ks} / \mathrm{Kr}$ adalah ripple factor, dan $\mathrm{L}$ adalah lebar sungai $(\mathrm{m})$. Parameter yang digunakan dalam rumus Meyer Peter and Muller (1948) menggunakan data sekunder sebagaimana penelitian dari Setiawan (2011), diantaranya: $\rho_{\mathrm{s}}$ sebesar $1000 \mathrm{~kg} / \mathrm{m}^{3}, \rho_{\mathrm{w}}$ sebesar $2595 \mathrm{~kg} / \mathrm{m}^{3}$, nilai $\mathrm{K}_{\mathrm{s}} / \mathrm{K}_{\mathrm{r}}$ dianggap 1, slope (S) sebesar 0,005, $\mathrm{d}_{50}$ sebesar 0,002 m, $\mathrm{d}_{90}$ sebesar 0,009 $\mathrm{m}$, void ratio sebesar 0,49, dan g sebesar $9,81 \mathrm{~m} / \mathrm{s}^{2}$. Lebar dari masing masing sungai adalah S. Serayu sebesar 25 m, S. Merawu sebesar 15 m, dan S. Lumajang sebesar $6 \mathrm{~m}$.

\section{Menghitung volume sedimen yang mengendap}

Besaran volume sedimen yang mengendap per tahun di waduk didapatkan berdasarkan data sekunder dari hasil pengukuran dengan metode echosounding. Pengukuran echosounding akan menghasilkan kapasitas tampungan dan laju endapan sedimen per tahun. Pemeruman dilakukan dengan menggunakan alat echosounder.

\section{Menghitung efisiensi tangkapan sedimen dengan data lapangan}

Besarnya nilai efisiensi (trap efficiency) didapatkan dengan dua cara, yaitu melalui data lapangan dan persamaan empirik. Berdasarkan data lapangan, nilai trap efficiency (TE) didapatkan dengan cara membagi sedimen yang mengendap dengan volume sedimen yang masuk, sebagaimana disajikan dengan rumus berikut.

$$
T E_{o b s}=\frac{D_{s}}{V_{s}} \times 100 \%
$$

Dimana :

$\mathrm{TE}_{\mathrm{obs}} \quad$ : efisiensi tangkapan (trap efficiency) terukur (\%)

$\mathrm{D}_{\mathrm{s}} \quad:$ sedimen total yang mengendap di waduk $\left(\mathrm{m}^{3}\right)$

$\mathrm{V}_{\mathrm{s}} \quad$ : sedimen total yang masuk ke waduk $\left(\mathrm{m}^{3}\right)$

Perhitungan nilai TE juga dilakukan berdasarkan persamaan empirik, diantaranya: Brown (1943), Churchill (1948), Brune (1953), Harbor et al (1997), dan Jothiprakash and Garg (2008), sebagaimana diuraikan sebagai berikut.

\section{Menghitung efisiensi tangkapan sedimen dengan metode Brown}

Menurut Brown (1944), nilai efisiensi tangkapan (trap efficiency) merupakan perbandingan antara rasio kapasitas tampungan dengan luas DAS sebagaimana dapat dilihat pada Gambar 2 grafik hubungan C/W dengan efisiensi tangkapan.

\section{Menghitung efisiensi tangkapan sedimen dengan metode Churchill}

Churchill (1948) mengembangkan hubungan antara efisiensi tangkapan (trap efficiency) dan indeks sediment waduk sebagaimana terlihat pada Gambar 3. Indeks Sediment (SI) adalah perbandingan antara waktu retensi dengan kecepatan rerata waduk. 


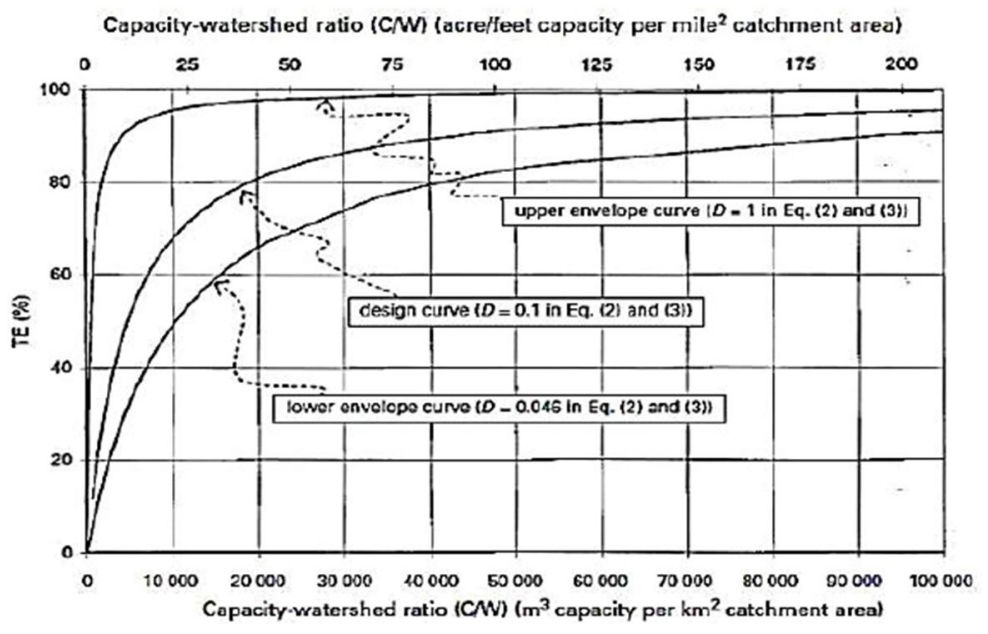

Gambar 2. Brown's trap efficiency Curve (Brown, 1944)

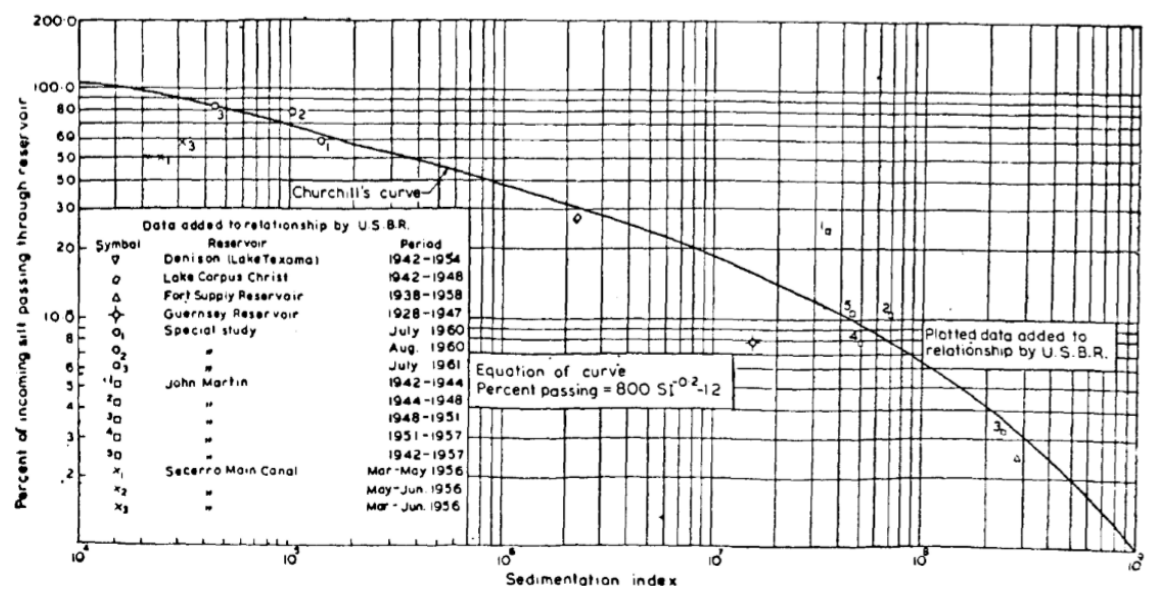

Gambar 3. Churchill's (1948) trap efficiency curve (Churchill, 1948)

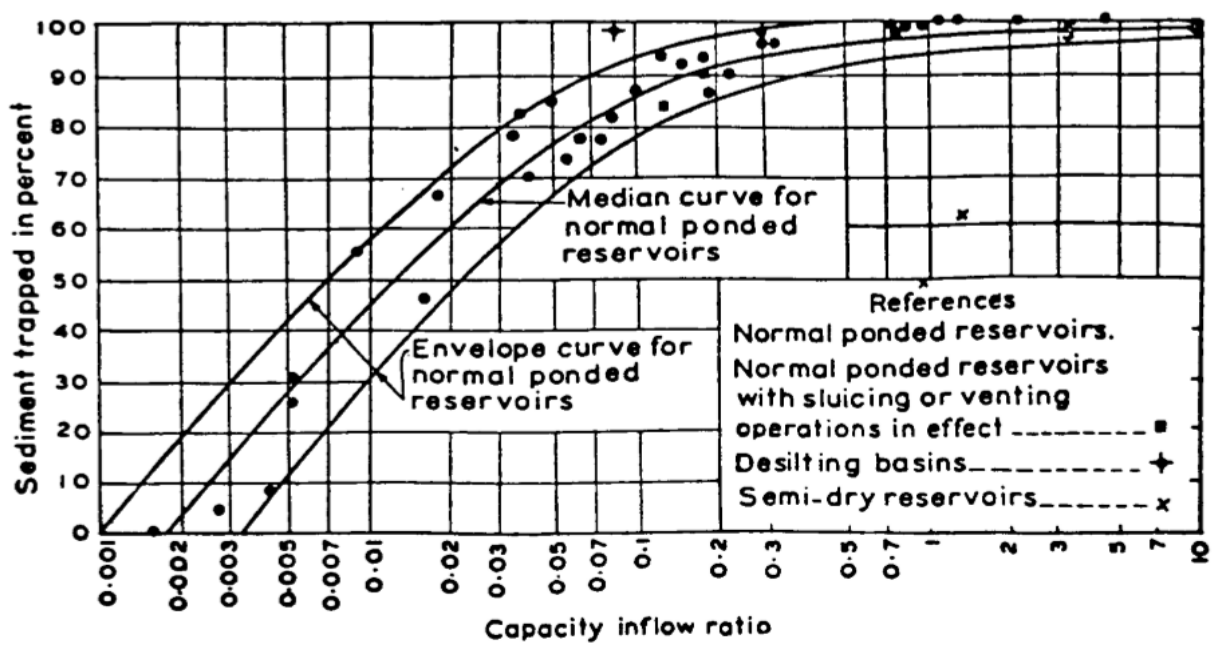

Gambar 4. Brune's Trap Efficiency Curve (Brune, 1953) 


\section{Menghitung efisiensi tangkapan sedimen dengan metode Brune}

Metode Brune dapat dilakukan dengan nomogram hubungan antara nilai efisiensi tangkapan (trap efficiency) dengan perbandingan antara kapasitas tampungan waduk dan inflow rerata tahunan sebagaimana terlihat pada Gambar 4.

\section{Menghitung efisiensi tangkapan sedimen dengan metode Harbor dkk}

Harbor dkk (1997) melakukan studi eksperimental terkait sedimentasi waduk dan mengembangkan persamaan empirik sebagai berikut:

$$
T E=-2+\left(\frac{119,2\left(\frac{C}{I}\right)}{0,012+1,02\left(\frac{C}{I}\right)}\right)
$$

dimana $\mathrm{C}$ adalah kapasitas tampungan waduk $\left(\mathrm{m}^{3}\right)$ dan I adalah inflow rerata tahunan $\left(\mathrm{m}^{3}\right)$

\section{Menghitung efisiensi tangkapan sedimen dengan metode Jothiprakash \& Grag}

Jothiprakash and Garg (2008) menemukan persamaan empirik lain yang diturunkan dari kurva Brune untuk medium sediment untuk menentukan nilai trap efficiency sebagaimana disajikan sebagai berikut.

$$
T E=\frac{\left(\frac{C}{I}\right)}{0,00013+0,01\left(\frac{C}{I}\right)+0,0000166 \sqrt{\frac{C}{I}}}
$$

Hasil simulasi dari beberapa metode estimasi nilai efisiensi tangkapan selanjutnya dievaluasi untuk mengetahui manakah yang memiliki tingkat akurasi yang tinggi dan tingkat kesalahan (error) yang paling kecil. Evaluasi metode trap efficiency dilakukan dengan metode statistik, seperti: korelasi (R), Relative Mean Error (RME), dan Root of Mean Square Error (RMSE) sebagaimana disajikan pada persamaan berikut.

$$
\begin{gathered}
R=\frac{\sum_{i=1}^{n} T E_{\text {cal }_{i}} x T E_{o b s_{i}}}{\sqrt{\left(\sum_{i=1}^{n} T E_{\text {cal }_{i}}^{2} x T E_{o b s_{i}}^{2}\right)}} \\
R M E=\frac{1}{n} \sum_{i=1}^{n} \frac{\left(T E_{o b s_{i}}-T E_{c a l_{i}}\right)}{T E_{o b s_{i}}} \\
R M S E=\sqrt{\frac{1}{n} \sum_{i=1}^{n}\left(T E_{o b s_{i}}-T E_{c a l_{i}}\right)^{2}}
\end{gathered}
$$

Dimana $T E_{o b s}$ adalah nilai trap efficiency terukur dari data lapangan dan $T E_{c a l}$ adalah nilai trap efficiency dari persamaan empirik. Tingkat akurasi dari metode dapat diketahui 
berdasarkan dari nilai korelasi dan tingkat kesalahan (error) dengan digolongkan berdasarkan Tabel 1 .

Tabel 1. Kriteria tingkat akurasi dari metode

\begin{tabular}{cccc}
\hline No. & Nilai Korelasi & Error $(\%)$ & Keterangan \\
\hline 1 & $0,00-0,19$ & $80-100$ & Sangat Lemah \\
\hline 2 & $0,2-0,39$ & $60-79$ & Lemah \\
\hline 3 & $0,4-0,59$ & $40-59$ & Sedang \\
\hline 4 & $0,6-0,79$ & $20-39$ & Kuat \\
\hline 5 & $0,8-1,0$ & $0-19$ & Sangat Kuat \\
\hline
\end{tabular}

\section{HASIL DAN PEMBAHASAN}

Sedimen yang masuk (sediment inflow) ke Waduk Mrica diprediksi melalui pendekatan angkutan sedimen di sungai. Debit sedimen total yang masuk ke waduk (total load) merupakan jumlah dari angkutan sedimen layang (suspended load) dan angkutan sedimen dasar (bed load). Sedimen layang (suspended load) menggunakan data hasil rating curve debit sedimen pada tiga sungai utama yang bermuara ke waduk dari PT. Indonesia Power. Perhitungan sedimen atau muatan dasar (bed load) dihitung melalui pendekatan rumus empirik angkutan sedimen dari Meyer Peter and Muller (1948), karena merupakan salah satu rumus empirik yang masih populer digunakan secara luas. Besaran volume sedimen yang mengendap per tahun di waduk didapatkan berdasarkan data sekunder dari hasil pengukuran dengan metode echosounding dari PT. Indonesia Power (2015). Selanjutnya dilakukan perhitungan nilai efisiensi tangkapan (trap efficiency) terukur dari data lapangan melalui persentase perbandingan antara sedimen total yang mengendap dalam waduk terhadap sedimen yang masuk waduk. Rekapitulasi hasil analisis sedimen yang masuk, mengendap, dan nilai efisien tangkapan sedimen dari data terukur disajikan pada Tabel 2.

Tabel 2. Rekapitulasi hasil analisis efisien tangkapan dari data terukur

\begin{tabular}{lrrrrrr}
\hline Tahun & $\begin{array}{l}\mathrm{V}_{\mathbf{s}} \text { Suspended } \\
\text { Load }\left(\mathbf{m}^{3}\right)\end{array}$ & $\begin{array}{l}\mathrm{V}_{\mathbf{s}} \text { Bed Load } \\
\left(\mathbf{m}^{3}\right)\end{array}$ & $\begin{array}{l}\mathrm{V}_{\mathbf{s}} \text { Total Load } \\
\left(\mathbf{m}^{3}\right)\end{array}$ & $\mathrm{D}_{\mathbf{s}}\left(\mathbf{m}^{3}\right)$ & $\mathrm{V}_{\text {out }}\left(\mathbf{m}^{3}\right)$ & \multicolumn{1}{c}{$\mathbf{T E}_{\text {obs }}$} \\
\hline 2001 & 3015414 & 2093316 & 5108730 & 3381701 & 1727029 & $66,19 \%$ \\
\hline 2002 & 3642203 & 2573254 & 6215457 & 3523077 & 2692380 & $56,68 \%$ \\
\hline 2003 & 3522583 & 2489704 & 6012286 & 44355166 & 1577120 & $73,77 \%$ \\
\hline 2004 & 2566661 & 1794707 & 4361368 & 2895168 & 1466200 & $66,38 \%$ \\
\hline 2005 & 3401713 & 2388766 & 5790479 & 4627772 & 1162707 & $79,92 \%$ \\
\hline 2006 & 3606908 & 2537740 & 6144648 & 3992261 & 2152387 & $64,97 \%$ \\
\hline 2007 & 2712362 & 1870354 & 4582716 & 3772284 & 810432 & $82,32 \%$ \\
\hline 2008 & 3195472 & 2235481 & 5430953 & 4299048 & 1131905 & $79,16 \%$ \\
\hline 2009 & 4269451 & 3011062 & 7280512 & 4763895 & 2516617 & $65,43 \%$ \\
\hline 2010 & 3918220 & 2752336 & 6670556 & 4054992 & 2615564 & $60,79 \%$ \\
\hline 2011 & 4943958 & 3501644 & 8445602 & 5318774 & 3126828 & $62,98 \%$ \\
\hline 2012 & 4294886 & 3023770 & 7318656 & 41417775 & 3176881 & $56,59 \%$ \\
\hline 2014 & 3257763 & 2278834 & 5536597 & 2480956 & 3055641 & $44,81 \%$ \\
\hline 2015 & 2448717 & 1679654 & 4128371 & 1707932 & 2420439 & $41,37 \%$ \\
\hline Laju rerata $/$ tahun & 4099641 & 2882388 & 6982029 & 4355431 & 2626598 & $62,38 \%$ \\
\hline
\end{tabular}

Hasil analisis total sedimen rerata tahunan yang masuk $\left(\mathrm{V}_{\mathrm{s}}\right)$ ke waduk mencapai sebesar 6,001 juta $\mathrm{m}^{3}$ /tahun. Sementara laju sedimentasi $\left(\mathrm{D}_{\mathrm{s}}\right)$ rerata tahunan mencapai 3,850 juta $\mathrm{m}^{3} /$ tahun. Hasil analisis menunjukkan bahwa sedimen yang keluar $\left(\mathrm{V}_{\text {out }}\right)$ dari waduk bervariasi antara 800 ribu -3 juta $\mathrm{m}^{3} /$ tahun. Sedimen yang dapat dikeluarkan terbesar 
mencapai 3,177 juta $\mathrm{m}^{3} /$ tahun pada tahun 2012 dan terkecil sebesar $810 \mathrm{ribu}^{3} /$ tahun pada tahun 2007. Total sedimen rerata yang dapat dikeluarkan dari waduk sebesar 2,151 juta $\mathrm{m}^{3}$ /tahun. Dari hasil analisis nilai $\mathrm{TE}_{\text {obs }}$ bervariasi antara $41,37 \%-82,32 \%$. Kondisi ini disebabkan karena pengelolaan sedimentasi di Waduk Mrica belum dilakukan secara berkesinambungan. Pada kondisi tertentu besarnya nilai $\mathrm{TE}_{\text {obs }}$ bisa mencapai $82,32 \%$ pada tahun 2007, tetapi ada juga nilai $\mathrm{TE}_{\text {obs }}$ yang sekitar $41,37 \%$ pada tahun 2014. Nilai $\mathrm{TE}_{\text {obs }}$ rerata dari data lapangan mencapai $64,25 \%$.

Dalam penelitian ini, besarnya nilai $\mathrm{TE}_{\mathrm{obs}}$ dibandingkan dengan $\mathrm{TE}_{\mathrm{cal}}$ dari berbagai persamaan empirik, diantaranya: Brown (1944), Churchill (1948), Brune (1953), Harbor dkk (1997), dan Jothiprakash and Garg (2008). Pemilihan persamaan empirik ini sendiri didasarkan pada kemudahan dan kepraktisan. Hasil analisis besarnya nilai $\mathrm{TE}_{\mathrm{cal}}$ dari berbagai rumus empirik disajikan dalam Gambar 5.

Dari Gambar 5 menunjukkan bahwa kecenderungan (trend) nilai trap efficiency waduk semakin menurun dari tahun ke tahun sebanding dengan penurunan kapasitas tampungan waduk. Berdasarkan nilai $\mathrm{TE}_{\text {cal }}$ (Brown) menunjukkan nilainya berkisar antara $90-100 \%$. Nilai $\mathrm{TE}_{\text {cal }}$ (Churchill) berkisar antara $80-90 \%$. Adapun nilai $\mathrm{TE}_{\text {cal }}$ (Brune) dan $\mathrm{TE}_{\text {cal }}$ (Jothiprakash and Garg) menunjukkan hasil yang hampir sama nilainya dan berkisar antara $60-80 \%$. Adapaun nilai $\mathrm{TE}_{\text {cal }}$ (Harbor dkk) menunjukkan hasil yang relatif lebih kecil dibandingkan dengan yang lain dan berkisar antara $50-75 \%$. Berdasarkan $\mathrm{TE}_{\text {cal }}$ (Churchil), $\mathrm{TE}_{\text {cal }}$ (Brune), $\mathrm{TE}_{\text {cal }}$ (Harbor dkk), dan $\mathrm{TE}_{\text {cal }}$ (Jothiprakash and Garg) memiliki pola yang bergelombang. Hal ini kemungkinan karena tidak adanya pengelolaan sedimentasi secara berkesinambungan. Sementara nilai $\mathrm{TE}_{\mathrm{cal}}$ (Brown) relatif memiliki pola garis lurus (linier) dan nilainya semakin kecil. Dari masing-masing persamaan empirik, terlihat bahwa pada tahun 2015 memiliki nilai $\mathrm{TE}_{\text {cal }}$ paling kecil.

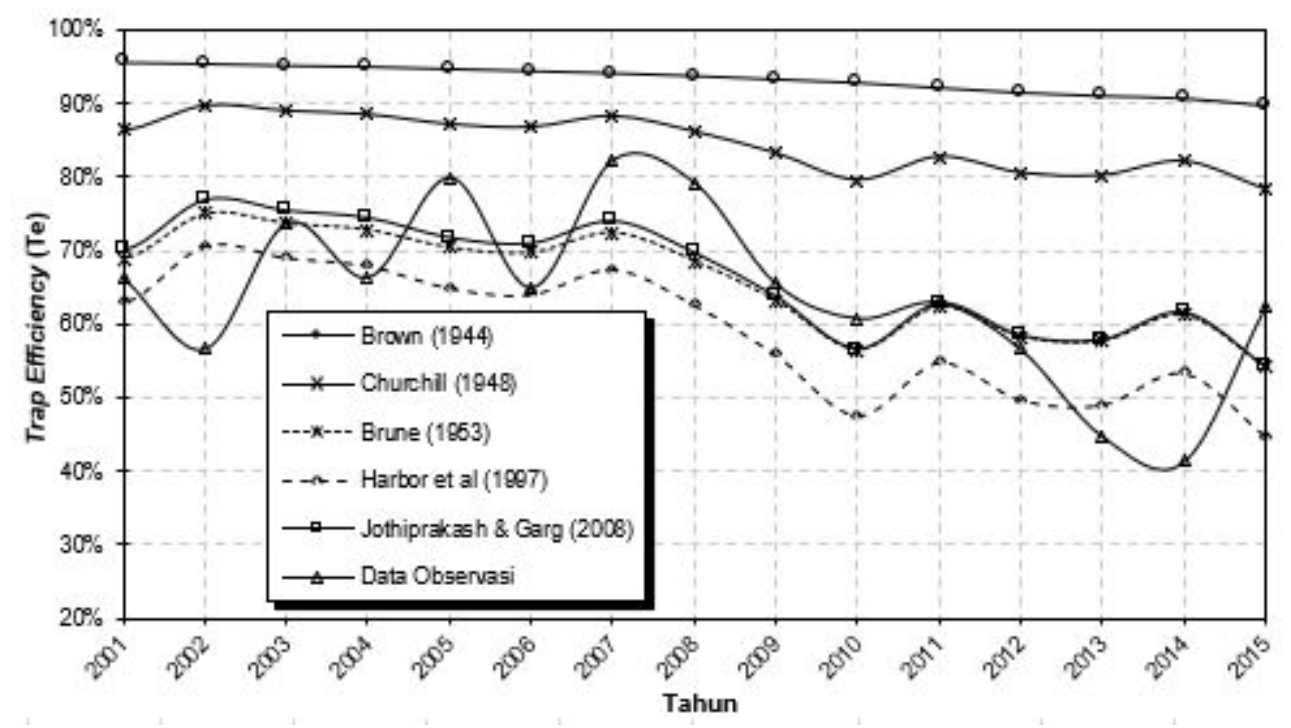

Gambar 5. Nilai TEcal dari berbagai persamaan empirik

Hasil simulasi dari beberapa metode estimasi nilai efisiensi tangkapan selanjutnya dievaluasi untuk mengetahui metode manakah yang memiliki tingkat akurasi yang tinggi dan tingkat kesalahan (error) yang paling kecil. Evaluasi yang digunakan dalam penelitian ini menggunakan 3 kriteria statistik, yaitu: nilai korelasi, RME, dan RMSE dan hasilnya sebagaimana disajikan pada Tabel 3. 
Tabel 3. Evaluasi dari metode TEcal dari persamaan empirik

\begin{tabular}{llllll}
\hline No. & Metode & Nilai Korelasi & RME (\%) & RMSE (\%) & Keterangan \\
\hline 1. & Brown & 0,407 & 50,434 & 30,820 & Sedang \\
\hline 2. & Churchill & 0,536 & 36,088 & 22,536 & Sedang \\
\hline 3. & Brune & 0,646 & 13,638 & 9,522 & Kuat \\
\hline 4. & Harbor et al & 0,647 & 15,755 & 10,951 & Kuat \\
\hline 5. & Jothiprakash dan Garg & 0,647 & 13,976 & 9,735 & Kuat \\
\hline
\end{tabular}

Nilai korelasi yang berada pada rentang 0 sampai 1 menunjukkan bahwa metode dapat diterima, tetapi perlu dilihat seberapa kuat hubungannya. Metode Brown yang memiliki nilai korelasi sebesar 0,407 , memiliki hubungan sedang terhadap nilai $\mathrm{TE}_{\mathrm{obs}}$ dari data lapangan. Metode yang paling memiliki nilai korelasi tinggi terdapat pada metode Harbor dkk, Brune, dan Jothiprakash dan Garg sebesar 0,647. Hasil perhitungan korelasi belum cukup untuk digunakan dasar dalam menentukan metode yang memiliki tingkat akurasi yang tinggi. Semua metode memiliki korelasi yang cukup terhadap nilai efisiensi tangkapan dari data lapangan. Evaluasi dapat dilakukan menggunakan grafik perbandingan nilai TE obs pada grafik metode yang digunakan, seperti disajikan pada Gambar 6.

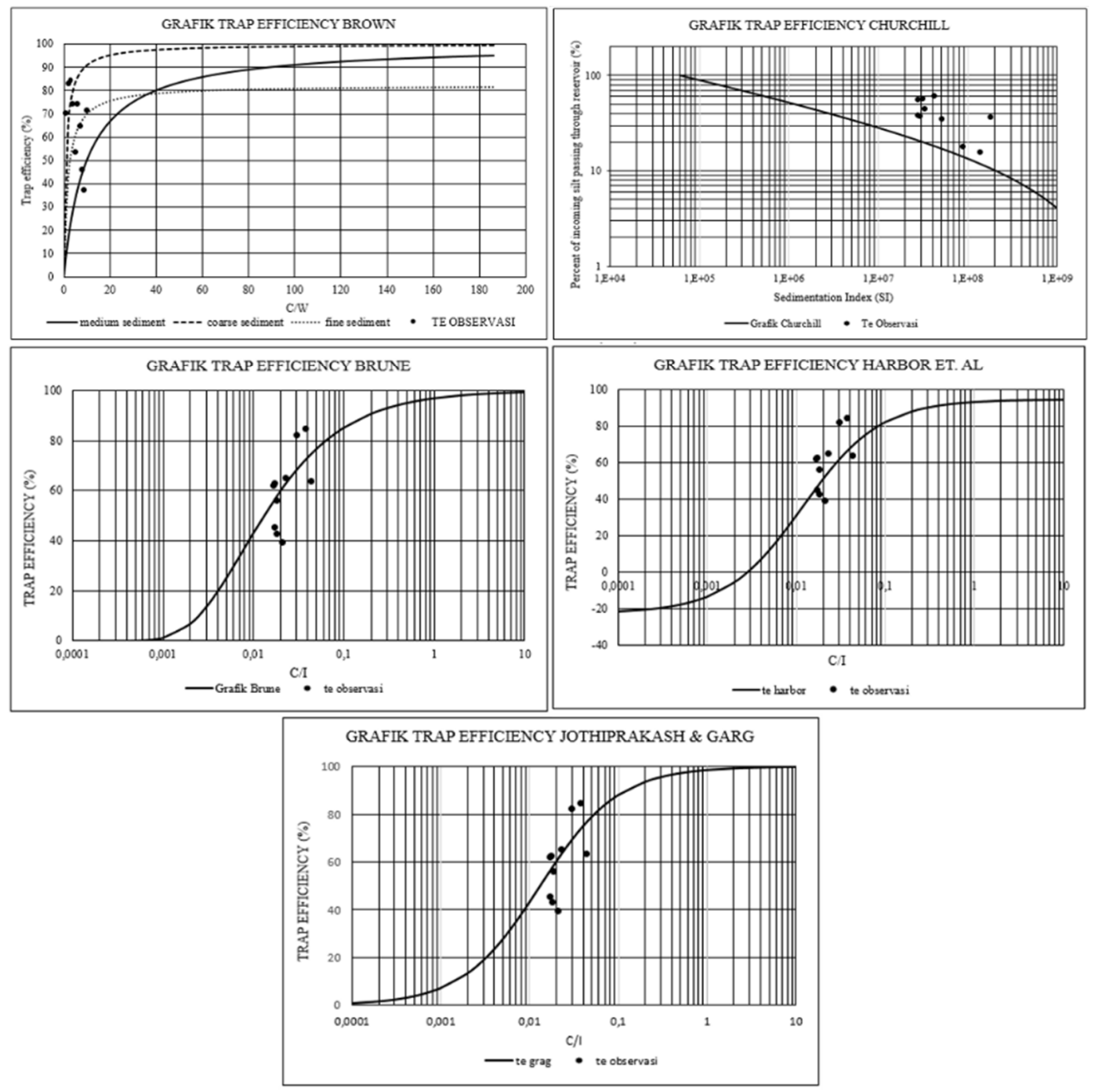

Gambar 6. Grafik perbandingan metode efisiensi tangkapan sedimen 
Gambar 6 menunjukkan bahwa nilai $\mathrm{TE}_{\text {obs }}$ tidak berada di garis metode $\mathrm{TE}_{\text {cal }}$ yang telah ditentukan untuk metode Brown dan Churchill. Metode ini memang memiliki korelasi sedang, tetapi tidak dapat mewakili nilai $\mathrm{TE}_{\text {obs }}$ karena nilainya tidak berada digaris $\mathrm{TE}_{\text {cal }}$ metode. Gambar 6 juga menunjukkan bahwa nilai $\mathrm{TE}_{\text {obs }}$ berada di sekitar garis $\mathrm{TE}_{\text {cal }}$ dari metode Brune, Harbor dkk, dan Jothiprakash \& Grag. Selain itu metode TE cal $_{\text {Brune, Harbor }}$ dkk, dan Jothipraash \& Grag dari perhitungan korelasi maupun evaluasi menggunakan grafik metode juga menunjukkan bahwa korelasinya kuat.

Sementara dari hasil evaluasi menggunakan RME dan RMSE (Tabel 3.) bahwa semakin kecil nilai RME dan RMSE, maka metode tersebut akan semakin baik. Hasil analisis didapatkan metode Brown memiliki nilai RME dan RMSE terbesar, yaitu 50,434\% dan $30,820 \%$. Kondisi ini menunjukkan bahwa metode ini memiliki tingkat kesalahan yang paling besar daripada metode lainnya. Metode yang memiliki nilai RME dan RMSE yang tekecil adalah metode Brune sebesar 13,638\% dengan nilai RMSE sebesar 9,522\%.

Evaluasi metode ini menunjukkan berdasarkan nilai R, RME, dan RMSE dapat diketahui bahwa metode yang memiliki tingkat akurasi kuat yaitu, metode Brune, Harbor dkk, dan Jothiprakash \& Grag sementara tingkat akurasi dari metode Brown dan Churchill dalam kriteria sedang. Oleh karena itu, metode estimasi nilai efisiensi tangkapan ( $\left.\mathrm{TE}_{\mathrm{cal}}\right)$ Brune, Harbor et al, dan Jotihiprakash dan Garg dianggap paling representatif untuk digunakan pada Waduk Mrica. Kondisi ini sesuai dengan penelitian yang dilakukan Susilo (2001) pada 13 waduk yang ada di Pulau Jawa, dimana metode Brune (1953) yang telah dimodifikasi adalah metode terbaik untuk prediksi efisiensi tangkapan sedimen waduk dibandingkan dengan metode prediksi Brown (1944) dan Churchill (1947).

\section{KESIMPULAN}

Imbangan sedimen pada Waduk Mrica menunjukkan bahwa laju sedimen yang masuk sebesar 6,001 juta $\mathrm{m}^{3} /$ tahun. Sedimen rerata yang mengendap di waduk sebesar 3,850 juta $\mathrm{m}^{3} /$ tahun, sehingga sedimen yang dikeluarkan rerata sebesar 2,151 juta $\mathrm{m}^{3} /$ tahun. Tingkat akurasi dari metode efisiensi tangkapan bervariasi dari sedang sampai kuat. Kecenderungan (trend) nilai trap efficiencywaduk semakin menurun dari tahun ke tahun sebanding dengan penurunan kapasitas tampungan waduk. Hasil evaluasi metode estimasi nilai efisiensi tangkapan sedimen menunjukkan metode Brune, Harbor dkk, dan Jotihiprakash and Garg dianggap paling representatif untuk digunakan pada Waduk Mrica dengan nilai korelasi ( $\mathrm{R}$ ) $>0,6, \mathrm{RME}<20 \%$, dan $\mathrm{RMSE}<20 \%$. Diharapkan dengan penelitian ini, dapat digunakan sebagai acuan oleh pihak pengelola waduk untuk mengestimasi imbangan sedimen melalui pendekatan konsep efisiensi tangkapan (trap efficiency) sedimen, tanpa pelaksanaan di lapangan karena pertimbangan biaya pelaksanaan yang cukup mahal. Selanjutnya diharapkan ada penelitian lanjutan dengan cara memodifikasi metode sehingga didapatkan metode baru yang dikembangkan, dengan studi kasus beberapa waduk di Indonesia.

\section{DAFTAR PUSTAKA}

Brown, C. B. (1944). Discussion of Sedimentation in Reservoirs. Trans. Am. Geophysical Union, 34(3), 407-418.

Brune, G. M. (1953). Trap Efficiency of Reservoirs. Proceedings of the American Society of Civil Enggineers, 1493-1500.

Churchill, M. A. (1948). Discussion of "Analysis and Use of Reservoir Sedimentation Data". In L. C. Gottschalk (Ed.), Proceedings of Federal Interagency Sedimentation Conference (pp. 139-140).

Dendy, F. E. (1974). Sediment trap efficiency of small reservoirs. Transactions of the ASAE, 17(5), 898-901. 
Drajati, C. S. E., \& Utomo, P. (2018). Kajian Imbangan Sedimen di Waduk Mrica Kabupaten Banjarnegara Provinsi Jawa Tengah. Civil Engineering and Environmental Symposium 2018.

Febriani, P., \& Utomo, P. (2018). Kajian Tingkat Akurasi Model Efisiensi Tampungan (Trap Efficiency) Sedimen Di Waduk Mrica Jawa Tengah. University of Technology Yogyakarta.

Garg, V., \& Jothiprakash, V. (2008). Estimation of useful life of a reservoir using sediment trap efficiency. Journal of Spatial Hydrology, 8(2).

Gill, M. A. (1979). Sedimentation and useful life of reservoirs. Journal of Hydrology, 44(1-2), 89-95.

Harbor, J., Bhaduri, B., Angelakis, L., \& Snyder, J. (1997). Sediment basins, using modified stormwater management basins and sediment basins to reduce water pollution from construction sites in Ohio. Dept. of Geology, Kent State Univ., Kent, Ohio.

Heinemarm, H. G. (1981). A new sediment trap efficiency curve for small reservoirs 1. JAWRA Journal of the American Water Resources Association, 17 (5), 825-830.

Meyer-Peter, E., \& Müller, R. (1948). Formulas for bed-load transport. IAHSR 2nd Meeting, Stockholm, Appendix 2.

Perum Jasa Tirta 1. (2015). Roadmap Pengelolaan Sedimentasi Waduk Mrica, Wadaslintang, Sempor di Wilayah Sungai Serayu Bogowonto.

PT. Indonesia Power. (2015). Laporan Pelaksanaan Penyelidikan Sedimentasi Waduk PLTA PB. Soedirman 2014. Unit Bisnis Pembangkitan Mrica.

Siyam, A. M. (2000). Reservoir sedimentation control. University of Bristol.

Susilo, E. (2001). Kajian Efisiensi Tangkapan Sedimen pada Beberapa Waduk di Jawa. Program Pascasarjana Universitas Diponegoro.

Utomo, P. (2017). Mrica Reservoir sedimentation: current situation and future necessary management. Journal of the Civil Engineering Forum Vol, 3(2).

Verstraeten, G., \& Poesen, J. (2000). Estimating trap efficiency of small reservoirs and ponds: methods and implications for the assessment of sediment yield. Progress in Physical Geography, 24(2), 219-251.

Widarto, O. L. I. (2017). Kajian Erosi Lahan Di Daerah Tangkapan Waduk Panglima Besar Soedirman Dan Analisis Sedimentasi. Universitas Gadjah Mada. 